\title{
Dynamics of soil organic carbon (SOC) content in stands of Norway spruce (Picea abies) in central Europe
}

\author{
Petra Bečvářová (1), \\ Marián Horváth ${ }^{(1)}$, \\ Bořivoj Šarapatka ${ }^{(1)}$, \\ Václav Zouhar ${ }^{(2)}$
}

\begin{abstract}
Norway spruce is the main forest tree species in the Czech Republic. Until now, little attention has been given in the literature to the dynamics of soil organic carbon (SOC) content under Norway spruce stands as a function of stand characteristics. The aim of this study is to estimate soil organic carbon (SOC) content and stock changes in organic and surface mineral soil horizons on forest sites with a dominant representation of Norway spruce. In the study area, a significantly higher content of SOC was found in the surface mineral soil horizon than in the organic soil horizon. In both soil horizons, there was evidence of an increasing trend of SOC with the increasing age of forest stands, a decreasing trend of SOC with increasing density of stocking and an increasing trend of SOC with increasing altitude. The relationship of SOC content with soil group (Podzol vs. non-Podzol) has also been demonstrated. The greatest potential for long-term carbon sequestration in soils was shown in older stands (101-190 years) dominated by Norway spruce with lower density of stocking, located in forest vegetation zones (altitude range: 1010-1225 $\mathrm{m}$ a.s.l.) where natural mountain Norway spruce forests currently occur. According to our results, Norway spruce stands may perform a stable function of carbon sequestration in the soil at these sites, especially in the mineral soil horizon.
\end{abstract}

Keywords: Forest Soil, C Sequestration, Picea abies, Site Conditions, Stand Characteristics, Climate Change

\section{Introduction}

It is estimated that forest ecosystems currently store more than $80 \%$ of all terrestrial aboveground carbon (C) and approximately $45-70 \%$ of all soil carbon (Post et al. 1990, Birdsey et al. 1993, Lorenz \& Lal 2010). The role of forests in the global carbon cycle, and in mitigation of the impact of climate change, is clear and fairly well documented (IPCC 2000, Janssens et al. 2003, Ciais et al. 2008, Lorenz \& Lal 2010). The study of the carbon cycle and its stocks and fluxes has come to the forefront of interest over the last 10 years, es pecially in relation to limiting the effects of global warming.

In terms of the predicted impact of climate change (the scenario of "Business as Usual" developed by IPCC and the global scenarios by Goddard Institute - Čermák et al. 2004) and according to regional scenarios for the Czech Republic (in 2030), it is likely that the most affected stands will be the Norway spruce (Picea abies [L.] Karst.) stands in the current $3^{\text {rd }}$ and $4^{\text {th }}$ forest vegetation zones (FVZ - Viewegh et al. 2003), where it is expected that they will almost completely disappear. The occurrence of Norway spruce in this area will likely be restricted to the highest mountainous border region (from the $5^{\text {th }} \mathrm{FVZ}$ upwards - Čermák et al. 2004, Čermák \& Holuša 2010, Hlásny et al. 2011, Fitzgerald \& Lindner 2013, Hanewinkel et al. 2013).

Norway spruce represents about $38 \%$ of trees in the European forests, and it is the dominant forest tree species (52-53\%) in the Czech Republic, although its share
(1) Department of Ecology and Environmental Sciences, Faculty of Science, Palacký University Olomouc, Šlechtitelů 27, 78371 Olomouc - Holice (Czech Republic); (2) Forest Management Institute, Brandýs nad Labem, Branch Brno, Vrázova 1, 61600 Brno - Žabovřesky (Czech Republic)

@ Bořivoj Šarapatka (borivoj.sarapatka@upol.cz)

Received: Jun 13, 2017 - Accepted: Aug 11, 2018

Citation: Bečvářová $P$, Horváth $M$, Šarapatka B, Zouhar V (2018). Dynamics of soil organic carbon (SOC) content in stands of Norway spruce (Picea abies) in central Europe. iForest 11: 734-742. - doi: 10.3832/ifor2521-011 [online 2018-11-06]

Communicated by: Carlotta Ferrara should not exceed $11 \%$ in the natural forest tree communities of this region. Indeed, Norway spruce naturally occurs on modal sites from the $5^{\text {th }} \mathrm{FVZ}$ (520-730 $\mathrm{m}$ a.s.l.), with an admixture (up 20\%) of beech (Fagus sylvatica) and silver fir (Abies alba), up to $8^{\text {th }}$ FVZ (1170-1225 $\mathrm{m}$ a.s.I.) where it is the dominant tree species. However, Norway spruce in the Czech Republic is also cultivated outside of its optimum elevation range (in particular, in the $2^{\text {nd }}, 3^{\text {rd }}$ and $4^{\text {th }}$ FVZ), and this could be one of the factors related to the significant dieback of this tree species in Czech forests in recent decades.

According to several authors (Berger et al. 2002, Körner 2006) Norway spruce growing in its ecological optimum will play a relatively important role in facing global climate change, mainly in terms of carbon sequestration and storage. However, it is very important to know the optimum conditions for carbon sequestration, as the potential for sequestration of carbon is influenced by site conditions (such as climate, temperature, etc. - Wiesmeier et al. 2013, Tashi et al. 2016) and soil conditions (soil moisture, $\mathrm{pH}$, nutrients, texture), as well as species composition, the applied form of management and its intensity (Jandl et al. 2007, Vesterdal et al. 2008, Wiesmeier et al. 2013, Vilén et al. 2015, Lundmark et al. 2016).

The aims of this study were: (i) to analyse the state and development of the carbon stock in the organic (O) and surface min- 
eral (A) soil horizon in forest sites where Norway spruce is the dominant species; (ii) to study the relationships of selected stand characteristics (age, density of stocking and absolute height-yield class) with SOC content in the organic and surface minera soil horizons under different site conditions (altitude, soil type, humus form); (iii) to assess the ability of Norway spruce stands to sequester carbon during stand development and their response to productive forest management in relation to vegetation zonality; (iv) to estimate optimum conditions for carbon sequestration in Norway spruce stands. The study could contribute to better understand current dieback of Norway spruce forests in central Europe and under the expected climate change.

\section{Material and methods}

\section{Study area}

For the purpose of this study, data was taken from the database of forest typology compiled by the Czech Forest Management Institute (FMI, Brandýs nad Labem, Czech Republic - http://www.uhul.cz/whatwe-do/forest-typology). The database includes information about forests from monitoring plots established all over the country, including soil conditions, species composition and mensurational characteristics of forest stands.

Forty-two monitoring plots were selected from the forest typology database, including their soil samples taken in the years 1975 to 2003. The size of the selected circular plots varied in the range of $400-500 \mathrm{~m}^{2}$. All the selected plots are located in the eastern part of the Czech Republic, in the Jeseníky Mountains and in the Drahanská vrchovina Upland (Fig. S1 in Supplementary material), at elevation ranging from 300 to $1318 \mathrm{~m}$ a.s.l., with mean annual air temperature (MAAT) varying from 2.1 to $8.1^{\circ} \mathrm{C}$ and mean annual precipitation (MAP) between $617 \mathrm{~mm}$ and $1106 \mathrm{~mm}$.

Soil conditions at the selected plots are variable. According to the World Reference Base (WRB 2014), soil groups were mainly represented by Cambisols, Podzols (Haplic and Entic Podzol), Stagnosols and Retisols. The dominant soil group in the selected set are Cambisols, and the prevailing humus form is moder. In each soil pit, two soil horizons (organic and surface mineral) were differentiated. The thickness of organic ( $\mathrm{O}$ ) horizons in the studied plots ranged from 2 to $15 \mathrm{~cm}$ (mean $=6.55 \mathrm{~cm}$ ), while the thickness of surface mineral $(A)$ horizons ranged from 1 to $27 \mathrm{~cm}$ (mean = $8.80 \mathrm{~cm})$. The depth of the two horizons $(\mathrm{O}+\mathrm{A}$ horizons) was in the range of $5-30 \mathrm{~cm}$ $($ mean $=15.33 \mathrm{~cm})$.

\section{Stand description}

We selected monitoring plots with dominant representation (91-100\%) of Norway spruce. Forest sites at the monitoring plots were included in units of the Typological forest classification system (Viewegh et al. 2003) used in the forests of the Czech Republic. This system includes site conditions (climate, soil, nutrients) and their relation to forest stands, including phytocenosis. In the Typological forest classification system (and in forest typology) the term of "forest vegetation zone" (FVZ) is used. FVZ is a formalized forestry unit expressing the relationship between climate and biocenosis, and describes in a simplified form the vegetation zones. According to the above classification system, the selected plots were included to FVZ from the $2^{\text {nd }}$ to the $9^{\text {th }}$. Samples from the plots were further classified in ecological series and edaphic categories (see Tab. S1 in Supplementary material).

The monitoring plots mostly consist of productive forest under continuous management. Species composition is regulated in the first 10 years by the reduction of density of advance growth and thinning out seedlings. From 10 to 25 years of age, tree species composition and its spatial distribution is regulated through cleaning (juvenile thinning). At age $25-60$, thinning is carried out to increase the ecological stability and resilience, and to support the growth of promising individuals. At age $60-80$, density of stocking is reduced to achieve a diameter increment. From 80 years of age, stands reach the felling maturity, forests undergo regeneration, eventually after-regeneration. The rotation period (regulated by law) is in the range of 70 to 170 years for Norway spruce, while in modal sites it fluctuates around 110 years.

The age of tree layer (range: 21-190 years) was classified into 8 age classes of 20-year intervals; the two oldest stands (aged 180 and 190 years) were assigned to the $8^{\text {th }}$ age class. Other variables included in the analysis were: the absolute height yield class (AHYC), i.e., the average height of forest stand at 100 years (range: $14-36 \mathrm{~m}$; modus: 28), reflecting the potential biomass production at a given site; and the density of stocking of forest stands, which is a categorical variable expressed as the ratio between the real stand basal area and the tabular stand basal area (range: 0.3-1). Stands with a value of density of stocking of 0.5 are not represented because of insufficient number of samples. Changes in the density of stocking in production forests are mainly due to targeted management interventions.

\section{Soil sampling and determination of soil organic carbon}

Soil samples were taken at the 42 selected monitoring plots during the growing season. Each plot was determined by the FMI as a representative site. Samples were taken from one soil pit (one soil pit at each plot), which was established in the central part of the plot. Before sampling, soil horizons $O$ and $A$ were determined and described. At each pit, one soil sample was taken from the organic (O) horizon and one from the surface mineral $(A)$ horizon
(42 soil samples in $\mathrm{O}+42$ soil samples in $\mathrm{A}$ ). Soil organic carbon (SOC) of samples was determined in a specialized laboratory at the FMI (Brandýs nad Labem, Czech Republic). Before analysis, each sample was homogenized separately for $\mathrm{O}$ and $\mathrm{A}$ horizons. SOC determination was conducted by the chromo-sulfuric oxidation method, accompanied by the titration of hydroquinone (wet method - Nelson \& Sommers 1982). Analysis of samples was performed in two replications. SOC values were converted from percentage units to tonnes per hectare $\left(\mathrm{t} \mathrm{ha} \mathrm{a}^{-1}\right)$ independently for the forest floor ( $\mathrm{O}$ horizon) and the surface mineral horizon (A), following to the methodology by Macků (Marek et al. 2011), by considering the thickness of individual horizons at each pit $(\mathrm{cm})$, the bulk density $\left(\mathrm{g} \mathrm{cm}^{-3}\right)$, and the SOC content (\%). According to the above authors, values of bulk density are different for each FVZ and ecological series, as well as soil horizon, and are part of the methodology.

\section{Statistical analysis}

Statistical analysis was conducted using the software STATISTICA ${ }^{\circledast}$ ver. 12.0 (StatSoft Inc., Tulsa, OK, USA) to obtain information about the relationships and dependencies among the studied variables. The data included the SOC content in the $O$ and A horizons, the depth of these horizons, humus forms and soil groups, as well as a set of abiotic variables at each plot associated with altitude (mean annual air temperature, mean annual precipitation, duration of the growing season as the sum of days with temperature above $10^{\circ} \mathrm{C}$ ). Moreover, stand characteristics were included in the analysis (age, density of stocking, absolute height-yield class), as well as site features (edaphic category, forest site, vegetation zonality). The Spearman's correlation coefficient was used to determine the relationships between quantitative variables.

Normality of distribution was verified for each variable using the Shapiro-Wilk test and by visualization of Quantile-Quantile graph (Q-Q graph) and Normal Probability graph (N-P graph). Non-parametric tests were applied where appropriate: the Mann-Whitney $U$ test for the comparison of SOC content between the Podzol and non-Podzol soil groups; the Kruskal-Wallis test followed by a post-hoc non-parametric multiple comparison for testing differences in SOC content among plots within different soil groups; the Wilcoxon signed rank test for comparison of SOC content in $\mathrm{O}$ and A horizons. Levene's test was used to verify the homogeneity of variance. The homogeneity of the data was additionally evaluated by calculating the coefficient of variation. Outlier identification was carried out using the non-parametric Dean-Dixon test. All tests were performed at $5 \%$ level of significance.

Since the SOC content has a non-normal distribution, the median values $\left(50^{\text {th }}\right.$ per- 


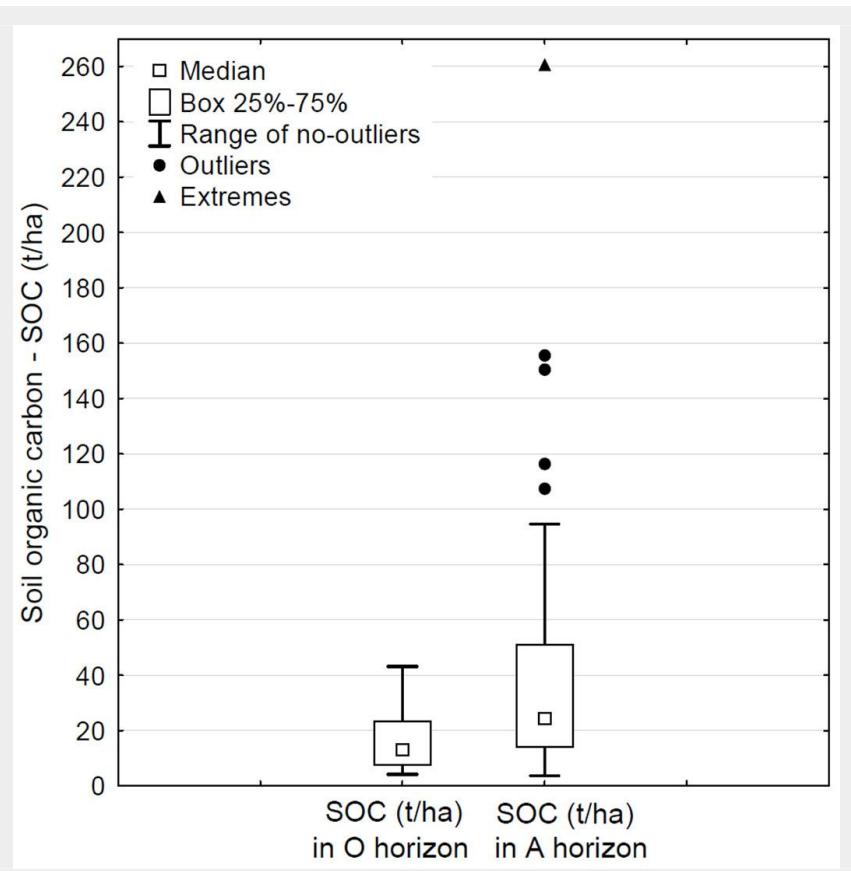

Fig. 1 - Comparison of SOC content ( $t$ ha $^{-1}$ ) in the organic $(O)$ and surface mineral $(A)$ soil horizons at the 42 monitoring plots examined in this study.

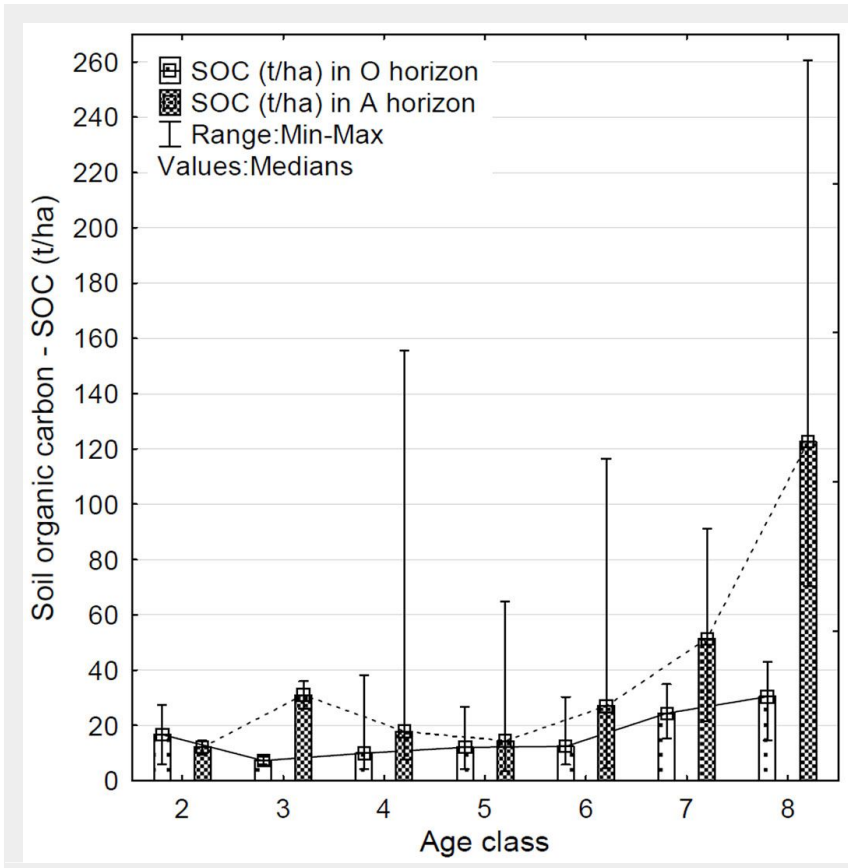

Fig. 2 - Variation of SOC content $\left(t \mathrm{tha}^{-1}\right)$ in the organic $(O)$ and surface mineral $(A)$ soil horizons in relation to stand age class in the studied plots. centile) were used to avoid possible bias of means due to outliers and extreme values. For the same reason, the min-max range is shown in figures; however, standard deviation (SD) and standard error of the mean (SE) for individual age classes and density of stocking are listed in Tab. S3 and Tab. S4 (Supplementary material), to allow a better comparison with median values. Outliers and extreme values were intentionally not removed from the dataset, as they provided one of the findings which are part of the results.

To identify the factors better accounting for SOC variability, linear regression models of log-transformed SOC content were fitted separately for $\mathrm{O}$ and $\mathrm{A}$ horizons. Firstly, categorical variables were included in the models, and then quantitative variables and their interactions with variables already included in the model were added. Only significant predictors (variables/interactions) were kept in the model. If the interaction between a quantitative and categorical variable was significant, the effect of a quantitative variable was also investigated in individual subgroups defined by the categorical variable.

For better understanding the relationships among quantitative variables, Principal Component Analysis (PCA) was performed and the first two principal components were visualized using a biplot.

\section{Results}

The content of SOC in the surface mineral (A) horizon varied within the range of 3.68 to $260.64 \mathrm{t} \mathrm{ha}^{-1}$ (with a median of $24.38 \mathrm{t}$ ha ${ }^{-1}$ ), with a marked variation due to the presence of several extreme values (outliers - Fig. 1). In the organic (O) horizon the content of SOC varied within the range of with the age class of stands (Fig. 2), with a 4.21 to $43.19 \mathrm{t} \mathrm{ha}^{-1}$ (with a median of $13.11 \mathrm{t}$ deviation in the $2^{\text {nd }}$ age class. The same deha ${ }^{-1}$ - Fig. 1). The content of SOC was higher pendence was demonstrated in the A horiin the $A$ horizon than in the $O$ horizon in 33 zon $(R=0.45 ; p<0.01)$ with deviations in monitoring plots with dominant represen- content of SOC in the $3^{\text {rd }}$ and $4^{\text {th }}$ age class tation of Norway spruce. In the remaining (Tab. S3 in Supplementary material). The 9 plots, a higher SOC content was found in highest content of SOC was detected in the organic horizon. The difference in SOC the $8^{\text {th }}$ (oldest) age class of stands in both content between horizons was statistically horizons. On the other hand, the lowest significant $(p<0.01)$.

A positive correlation between $\mathrm{SOC}$ content and stand age class was found for both $O$ and $A$ horizons. In particular, the content of SOC in the organic horizon increases significantly $(R=0.43 ; p<0.01)$ content of SOC in the O horizon was detected in the $3^{\text {rd }}$ age class, while in the $A$ horizon it was in the $2^{\text {nd }}$ and subsequently in the $5^{\text {th }}$ age class of stand. The fourth and fifth age classes in the A horizon are characterized by a decrease in the otherwise in-

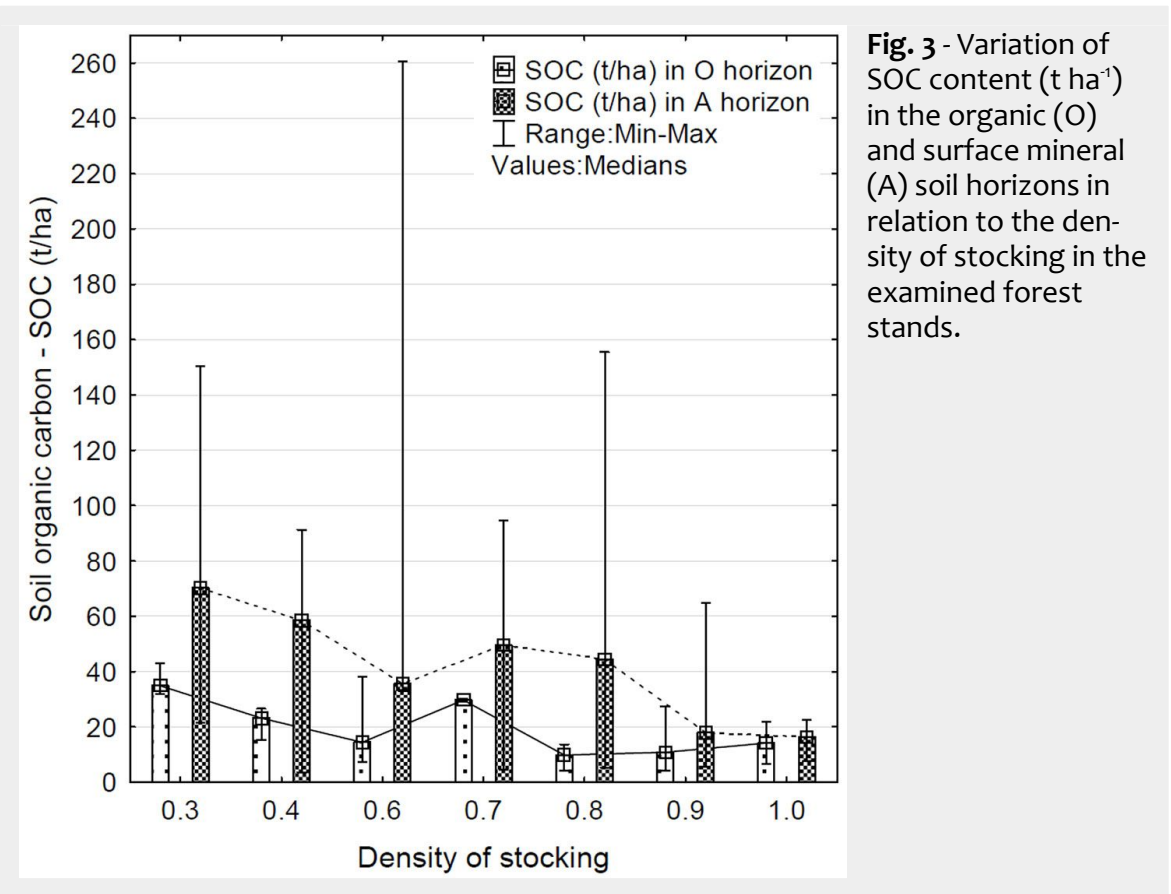




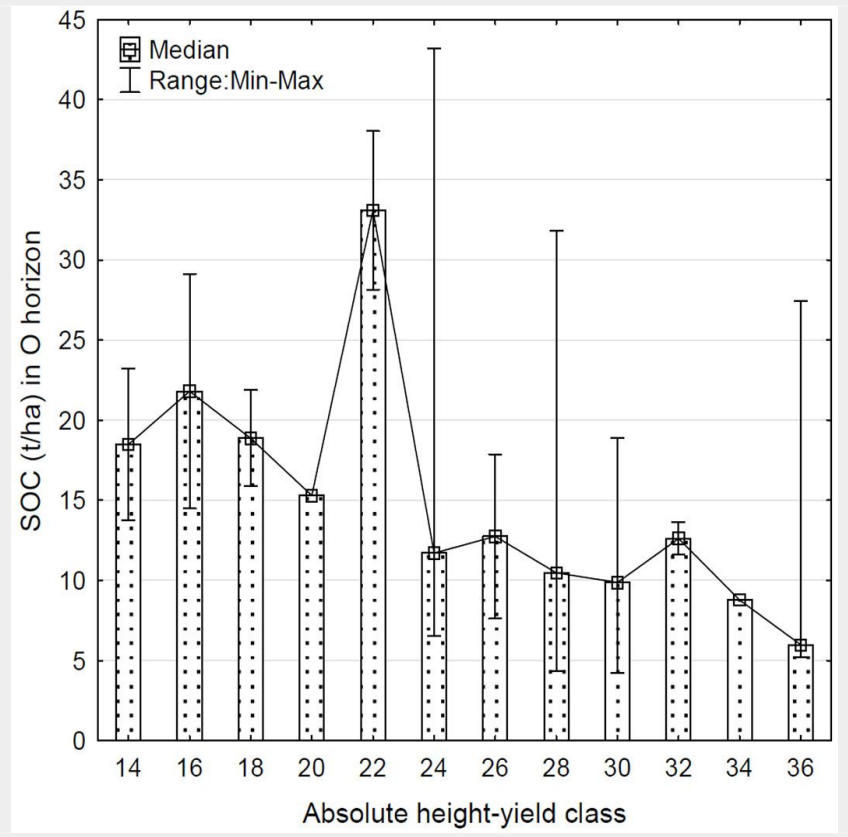

Fig. 4 - Variation of SOC content (t ha $\left.{ }^{-1}\right)$ in the organic (O) soil horizons in relation to the absolute height-yield class (AHYC) of stands.

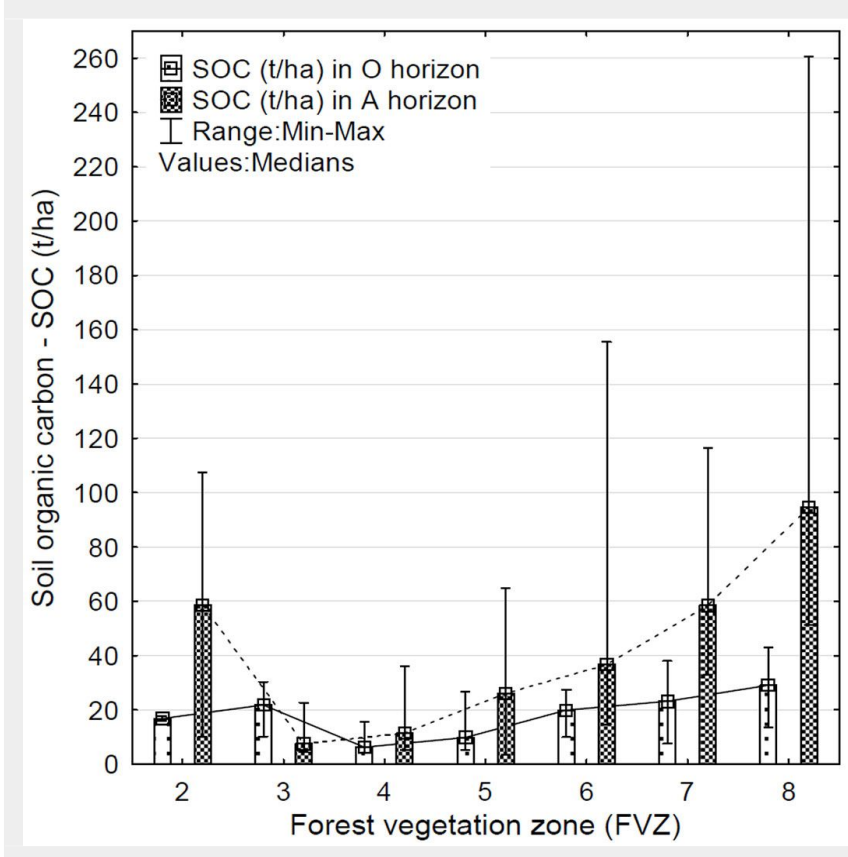

Fig. 5 - Variation of SOC content (t ha $\left.{ }^{-1}\right)$ in the organic $(O)$ and surface mineral $(A)$ soil horizons along an elevation gradient. (FVZ): forest vegetation zones (Viewegh et al. 2003). creasing trend of SOC. Values of SOC content in the $\mathrm{A}$ horizon from $4^{\text {th }}$ to $8^{\text {th }}$ age classes had the largest variation. The range of SOC values in the studied horizons accoring to the age class of stands are shown in Tab. S3 (Supplementary material).

Correlation analysis revealed a negative correlation between soil organic carbon (SOC) and the density of stocking for both horizons (Fig. 3). The content of SOC in the organic horizon decreases $(R=-0.39$; $p<$ 0.05 ) with increasing the density of stocking in the stand. The highest amount of SOC in the $O$ horizon was at a density of stocking of 0.3 , i.e., at the lowest values in the selected samples. The lowest amount of SOC in the $O$ horizon was determined at values of 0.8 and 0.9 . The correlation value of SOC with the density of stocking in the $A$ horizon was similar $(R=-0.36 ; p<0.05)$ to that of the $\mathrm{O}$ horizon. A considerable decline in the trend of SOC content in the A horizon is apparent when density of stocking is o.6. The lowest level of SOC in the mineral horizon was detected at a density of stocking of 1.0 and 0.9. On the other hand, the highest level was detected at a density of stocking of 0.3 and 0.4 . The content of SOC in the A horizon again showed a remarkable variation (Tab. S4 in Supplementary material) due to extreme values (outliers). The trend of variation in SOC values (median) at increasing density of stocking is shown in Fig. 3.

Analysis of the relationship between age class and density of stocking of stands revealed a negative correlation $(R=-0.52 ; p<$ 0.01 ), i.e., the density of stocking decreases when the age class increases. Up to the $5^{\text {th }}$ age class the value of density of stocking was relatively stable, while a decline occurs in the $6^{\text {th }}$ and $7^{\text {th }}$ age classes; also, $7^{\text {th }}$ and $8^{\text {th }}$ age classes include stands with considerable variation in density of stocking. Distribution of individual values of density of stocking in the age classes of stands in the study area are given in Tab. S2 (Supplementary material).

The relationship between the absolute height-yield class (AHYC) and SOC was also examined in the studied plots. A significant relationship was found, with a negative

Tab. 1 - Median values of SOC content ( $\left.t \mathrm{ha}^{-1}\right)$ in organic $(O)$ and surface mineral (A) soil horizons, site altitude and prevailing humus form, according to soil group (determined after WRB 2014) represented in the analysed data set.

\begin{tabular}{|c|c|c|c|c|c|c|}
\hline \multirow[b]{2}{*}{ Soil groups } & \multicolumn{2}{|c|}{ SOC $\left(t_{\text {ha }}^{-1}\right)$} & \multicolumn{2}{|c|}{ Altitude (m a.s.l.) } & \multirow{2}{*}{$\begin{array}{c}\text { Dominant } \\
\text { humus } \\
\text { form }\end{array}$} & \multirow{2}{*}{$\begin{array}{l}\text { Sample } \\
\text { size } \\
\text { (n) }\end{array}$} \\
\hline & $\begin{array}{c}0 \\
\text { horizon }\end{array}$ & $\begin{array}{c}\text { A } \\
\text { horizon }\end{array}$ & Range & Average & & \\
\hline Haplic Podzols (HP) & 28.15 & 58.52 & $820-1318$ & 1137 & mor & 10 \\
\hline Entic Podzols (EP) & 13.64 & 44.46 & $720-1206$ & 907 & \multirow{4}{*}{ moder } & 8 \\
\hline Cambisols (CA) & 10.86 & 17.21 & $300-680$ & 534 & & 18 \\
\hline Retisols (RE) & 8.40 & 16.94 & $390-475$ & 433 & & 2 \\
\hline Stagnosols (SG) & 6.66 & 12.66 & $420-650$ & 513 & & 4 \\
\hline
\end{tabular}

correlation between AHYC and SOC only in the $O$ horizon $(R=-0.48 ; p<0.01)$, indicating that when AHYC increases, the SOC content decreases in the organic horizon (Fig. 4), with the exception of AHYC values 16, 22 and 32. No significant correlation was found in the A horizon, though a decreasing trend of SOC in relation to AHYC in the surface mineral horizon was also evident (Fig. S2 in Supplementary material).

A significant relationship was also detected between SOC content and altitude (in terms of FVZ) in the organic ( $R=0.44 ; \mathrm{P}$ $<0.01)$ and surface mineral horizons $(R=$ $0.68 ; p<0.01)$. The content of SOC in the soil increased with increasing FVZ (Fig. 5). In Fig. 5 a gradually increasing trend of SOC is evident from $4^{\text {th }}$ to $8^{\text {th }} \mathrm{FVZ}$ for both horizons. A more pronounced increasing trend and a higher SOC content were detected in the A horizon. In the $4^{\text {th }} \mathrm{FVZ}, 6.34 \mathrm{t} \mathrm{ha}^{-1}$ of SOC was detected in the $O$ horizon, and $11.45 \mathrm{t} \mathrm{ha}^{-1}$ of SOC in the A horizon; in the $8^{\text {th }}$ FVZ the value of SOC in the O horizon was $29.14 \mathrm{t} \mathrm{ha}^{-1}$ and $94.63 \mathrm{t} \mathrm{ha}^{-1}$ in the A horizon. On the other hand, in the $3^{\text {rd }}$ and $9^{\text {th }} \mathrm{FVZ}$, a higher SOC content was detected in the $\mathrm{O}$ horizon as compared with the A horizon. The $2^{\text {nd }} \mathrm{FVZ}$ showed a deviation in an otherwise increasing trend of $\mathrm{SOC}$ in the A horizon, probably due to the low number of samples and/or the presence of several extreme values (Fig. 5).

SOC content in organic and surface mineral horizons and the altitude were also closely related to the type of soil (soil groups) and humus form (Tab. 1). The highest content of SOC was detected in the Podzol group of soils, which also included a large number of extreme values (Fig. 6). The highest content of SOC was found in 
Haplic Podzols in both horizons (28.15 and $58.52 \mathrm{t} \mathrm{ha}^{-1}$ in $\mathrm{O}$ and $\mathrm{A}$ horizons, respectively). These samples came from altitudes ranging from 820 to $1318 \mathrm{~m}$ a.s.l., where the predominant humus form was mor. Entic Podzols contained 13.64 and $44.46 \mathrm{t} \mathrm{ha}^{-1}$ of SOC in $\mathrm{O}$ and $\mathrm{A}$ horizons, respectively. These samples came from a range of altitudes from 720 to $1206 \mathrm{~m}$ a.s.l., where the dominant humus form was moder. The lowest content of SOC was detected in Stagnosols, with values of 6.66 and $12.66 \mathrm{t}$ ha $^{-1}$ for $\mathrm{O}$ and $\mathrm{A}$ horizons, respectively, and moder as prevalent humus form. Although the difference in SOC content among the five soil groups was significant $(p<0.01$ for both horizons), there was no significant difference between Haplic Podzol and Entic Podzol, and similarly there was no difference among Cambisols, Stagnosols and Retisols. Therefore, we distinguished two soil groups showing significantly different ( $p<0.01$ ) SOC content: the Podzol and the other (non-Podzol) groups.

SOC content also varied according to the present humus forms (mor and moder). A significantly higher content of SOC was found in samples with mor humus forms in both horizons ( $p<0.01$ - Fig. S3 in Supplementary material). The most pronounced difference in SOC content between mor and moder humus was in the surface mineral (A) horizon (about $40 \mathrm{t} \mathrm{ha}^{-1}$ ). In the organic (O) horizon a median value of $25.69 \mathrm{t}$ ha $^{-1}$ was observed, while in the A horizon a median of $64.38 \mathrm{t} \mathrm{ha}^{-1}$ was found for humus form mor.

\section{Log-linear models for SOC content}

In both soil horizons, SOC content was significantly higher in the Podzol soil group than in the non-Podzol soil group. The difference in SOC content between mor and moder humus forms was not significant either in Podzols or in non-Podzol soil groups. Previously observed differences between mor and moder humus forms can therefore be explained by a higher frequency of mor humus form in the Podzol soil group: 10 out of 18 Podzols were of mor humus form, whereas only 2 out of the 24 monitoring plots with non-Podzol soil group were of mor humus form.

As expected, all the environmental variables analyzed (mean annual precipitation, mean annual air temperature and duration of the growing season) were highly intercorrelated, as they represent abiotic conditions associated with the elevation gradient. Therefore, only altitude was taken into consideration for inclusion in the log-linear model.

In the Podzol soil group, none of the stand characteristics were significantly associated with SOC content in the organic (O) horizon. In the non-Podzol soil group, none of the variables representing abiotic conditions associated with altitude were significantly associated with SOC content. Neither were associations with age and density of stocking of stands significant.

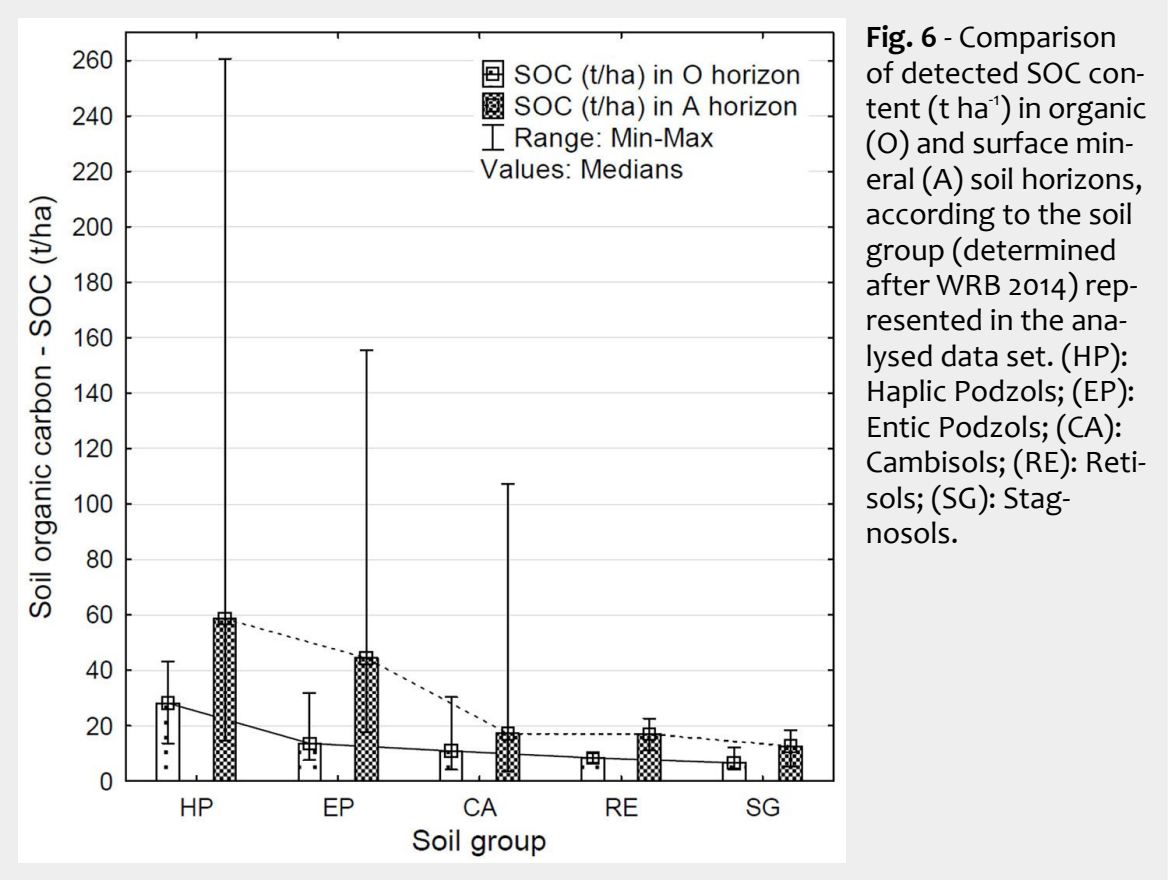

The only significant predictor of SOC content was AHYC $(p=0.03)$ in the non-Podzol soil group. The association was negative the higher SOC content in the $\mathrm{O}$ horizon was found in stands with low absolute height-yield class.

As regards the SOC content in the surface mineral (A) horizon, no significant association between SOC content and abiotic variables (altitude, mean annual air temperature, mean annual precipitation, duration of growing season) or stand characteristics (age class, density of stocking, AHYC) was found for neither soil groups. In the surface mineral horizon, it was evident that soil group had the most significant influence on SOC content. The effects of other variables were negligible.

The results of the bivariate analyses

showed that soil groups and altitude have a significant influence on SOC content in both horizons. However, when the samples were divided into the 2 groups of soils (Podzols and non-Podzols), the effect of altitude was no longer significant in the surface mineral (A) horizon, while it was significant only for the Podzol soil group in the organic (O) horizon.

\section{Principal components}

The PCA revealed the strong correlation among the abiotic variables associated with altitude, which was strongly positively correlated with mean annual precipitation and strongly but negatively correlated with mean annual air temperature and duration of growing season (Fig. 7). These variables had the highest loadings on the first princi-

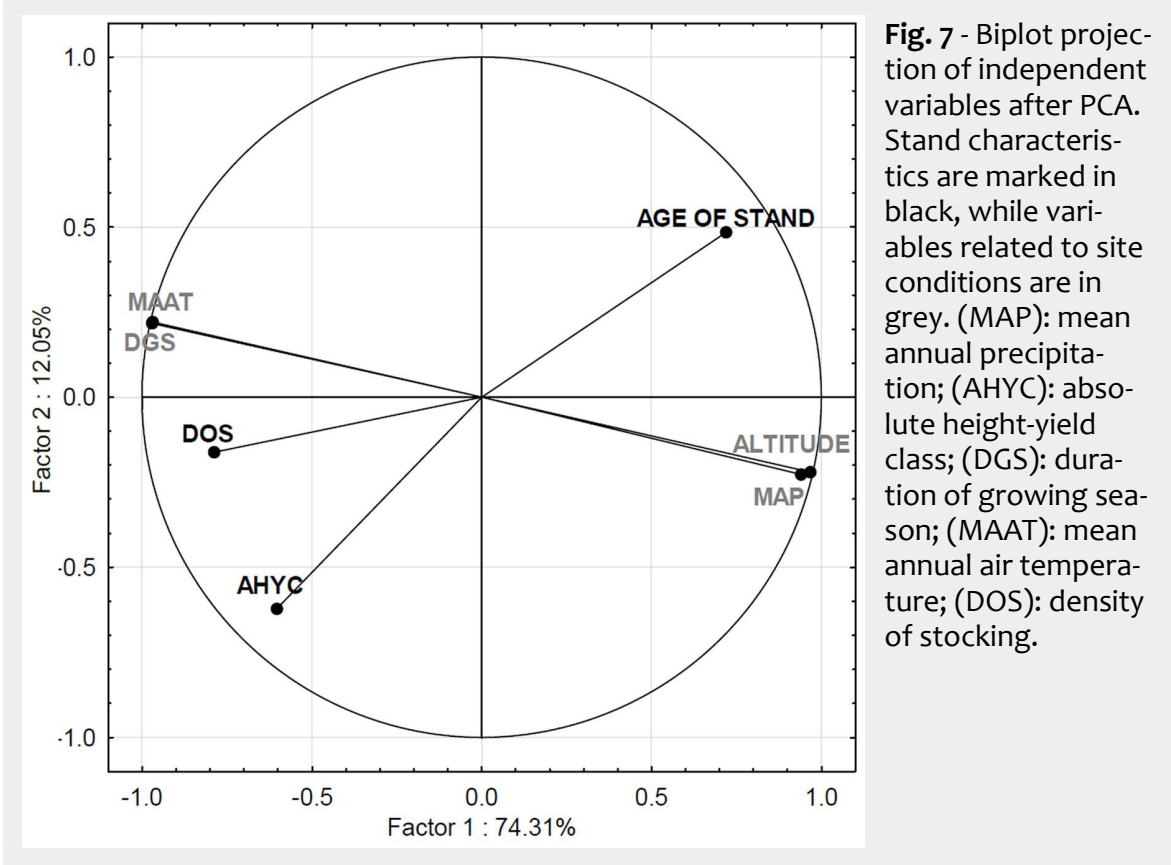


pal component, which explained the largest portion (74.3\%) of variability, and reflects the abiotic variables associated with the altitude gradient. The second principal component, which explains an additional $12.1 \%$ of variability, reflects stand characteristics, and revealed a positive correlation with density of stocking and absolute height-yield class and a negative correlation with stand age.

\section{Discussion}

Various studies has highlighted the role of forest ecosystems in the global carbon cy cle and in mitigating the impacts of global climate change (IPCC 2000, Janssens et al. 2003, Ciais et al. 2008, Lorenz \& Lal 2010, Vesterdal et al. 2013). The potential for carbon storage in the soil has been extensively investigated, mostly focusing on differences among soils beneath different forest tree species (mainly beech and spruce), or by comparing the stock of soil carbon in coniferous and deciduous stands (Oostra et al. 2006, Vesterdal et al. 2008, 2013).

In this work, we studied the potential for carbon sequestration in the soil of 42 rep resentative stands with dominant Norway spruce in the Czech Republic by analyzing their SOC content, with the aim of estimating its amount in the organic and surface mineral soil horizons and assessing the driving factors affecting SOC content. A number of authors (Vesterdal et al. 2013, Pretzsch et al. 2014, Vilén et al. 2015, Andivia et al. 2016, Tashi et al. 2016) agree that the potential for carbon sequestration in the soil is influenced by site conditions (altitude, soil type, soil depth, humus form, etc.) and stands characteristics (age, density of stocking and species composition).

In this study, the relationships between SOC content, abiotic variables, and stand characteristics have been tested by bivariate analysis, log-linear models and PCA. As expected, mean annual air temperature, mean annual precipitation, duration of growing season were highly dependent upon the altitude of the studied stands, represented here by the forest vegetation zones (FVZ). No particular attention has been given to well-known relationships that can be easily explained - for example, the decreasing density of stocking with increasing altitude.

Our results showed that the total SOC stock in forest stands with a dominant proportion of Norway spruce is in the range of 11.91 to $275.11 \mathrm{t} \mathrm{ha}^{-1}$ (with a median value of $37.49 \mathrm{t} \mathrm{ha}^{-1} \mathrm{SOC}$ ) in all the studied soil profiles ( $\mathrm{O}+\mathrm{A}$ horizon). A significantly higher SOC content was detected in 33 samples of Norway spruce stands in the surface mineral (A) horizon compared to the organic (O) horizon (Fig. 1). This corresponds with the studies by Vesterdal et al. (2008, 2013), who reported that tree species which have a low SOC content in the organic soil horizon have a higher content of $\mathrm{SOC}$ in the surface mineral soil horizon. A higher SOC content in the surface mineral horizon was also observed by previous studies carried out in Norway spruce stands (Gurmesa et al. 2013, James et al. 2014, Andivia et al. 2016). Contrastingly, a higher SOC content in the organic $(\mathrm{O})$ horizon was reported by several authors (Frouz et al. 2009, Harper \& Tibbett 2013, Wiesmeier et al. 2013). We observed a higher SOC content in the organic horizon only in 9 monitoring plots out of 42 , which can be attributed to the greater thickness of the organic horizon.

Many studies have compared SOC content in the soil organic horizon between different tree species, concluding that conifers in general (Pinus, Tsuga, Larix, Picea) and especially Norway spruce (P. abies) contain higher SOC stock in the organic horizon than other tree species (Oostra et al. 2006, Vesterdal et al. 2008, Frouz et al. 2009, Laganière et al. 2012, Gurmesa et al. 2013, Vesterdal et al. 2013, Kern et al. 2016). Indeed, the SOC content in this horizon is primarily influenced by species composition (Vesterdal et al. 2008, Gurmesa et al. 2013). Other authors also focused on SOC content in the surface mineral horizon, which is more affected by site conditions (Vesterdal et al. 2008, 2013, Gurmesa et al. 2013).

In the long term, it is preferable that carbon (SOC) is accumulated in the mineral horizon rather than in the organic horizon (Jandl et al. 2007, Frouz et al. 2009, Rumpel \& Kögel-Knabner 2011, Vesterdal et al. 2013). In fact, the organic horizon is more vulnerable as it is more influenced by both disturbances (e.g., cutting, fires) and decomposition processes, by which carbon could be released back into the atmosphere. Therefore, in terms of stable carbon sequestration into the soil, the mineral horizon plays a very important role.

In this study, we found that the SOC stock is significantly affected by stand characteristics, in terms of age, density of stocking and absolute height-yield class. An increasing trend in SOC with age class of the stand was detected both for the organic and surface mineral horizons. A similar trend was observed by Hiltbrunner et al. (2013) and Světlík et al. (2016). A slight decrease in the surface mineral horizon was evident in the $4^{\text {th }}$ (61-80 years) and the $5^{\text {th }}$ (81-100 years) age class. The lowest values of SOC were found in stands in the $5^{\text {th }}$ age class. Stands in the $4^{\text {th }}$ and $5^{\text {th }}$ age classes were mostly located at lower altitude, from $2^{\text {th }}$ to $5^{\text {th }} \mathrm{FVZ}$, in sites where forests with a dominance of Norway spruce are not natural. The prevailing humus form on these sites was moder. It is possible to presuppose that this decrease in the trend of SOC content may be caused by relatively better humification compared to higher FVZ. A faster decomposition retroactively releases carbon into the atmosphere as $\mathrm{CO}_{2}$, which in turn becomes available for potential sequestration of carbon into the tree biomass. The high ability of spruce to allocate carbon into its biomass in these age classes (especially $4^{\text {th }}$ and $5^{\text {th }}$ ) has been previously reported by several authors (Cienciala et al. 2006, Hiltbrunner et al. 2013, Vilén et al. 2015, Parolari \& Porporato 2016). This hypothesis has been also confirmed by a long-term research by Vilén et al. (2015), which was conducted in conifer (including Norway spruce) and broadleaved stands in the Czech Republic and Finland (from 1950-2010). The authors demonstrated that most carbon was allocated in tree biomass, especially in stands in the $4^{\text {th }}$ and $5^{\text {th }}$ age classes. According to Světlík et al. (2016), most carbon in Norway spruce is stored in the stem biomass (about $69.92 \%$ of the total carbon of individual tree biomass), while minor proportion are stored in the roots (16.80\%). Grünwald \& Bernhofer (2007) reported a carbon sequestration into biomass of 4-7 $t$ ha $^{-1}$ year $^{-1}$ in Norway spruce stands at aged 108 years in Germany. However, in coniferous stands with production management, the input of organic matter from tree biomass to forest soil is minimal. Indeed, tree stems with bound carbon are usually exported from such stands for further processing.

Stands of Norway spruce from $6^{\text {th }}$ to $8^{\text {th }}$ age class show a significantly increasing trend of SOC content and a high stock in the organic and surface mineral soil horizons (Fig. 2). In the case of $6^{\text {th }}$ age class, these are trees of felling maturity in production forests, while forest stands in the $7^{\text {th }}$ and $8^{\text {th }}$ age classes have a protective function in the study area, being located at higher altitudes ( $7^{\text {th }}$ and $8^{\text {th }} \mathrm{FVZ}$ ), where the dominant humus form is mor. In these sites, the decomposition rate decreases and there is an accumulation of organic matter and carbon in the soil (Drewnik 2006), which could explain the higher SOC content. Based on our results, we can conclude that these forest stands have a manifest potential to sequester carbon into the soil, predominantly in the surface mineral horizon (Carey et al. 2001, Jandl et al. 2007, Luyssaert et al. 2008).

The content of SOC and minor differences in both soil horizons in stands in the $2^{\text {nd }}$ age class can be explained by the influence of residual SOC content from the previous (cuttings) generation of forest. An increase in the difference of SOC content in organic and surface mineral horizons in the $3^{\text {rd }}$ age class can be explained by the displacement of the SOC stock through the root systems growing into the deeper layers of soil. Stands in these age classes were represented only by a low number of samples, and were found mainly at lower altitudes.

During the development of forest stands used for production, density of stocking is changed through management interventions, i.e., the density of stocking decreases with increasing age, as confirmed by the significant relationship between stocking density and stand age observed in this study. Stands up to the $5^{\text {th }}$ age class reached almost full stocking (the median value for density of stocking was 0.9), 
while a decrease occurs in the $6^{\text {th }}$ age class. The variation of the density of stocking from $4^{\text {th }}$ to $6^{\text {th }}$ age classes relates to the process of forest regeneration. Older protective forest stands in the $7^{\text {th }}$ and $8^{\text {th }}$ age class showed a lower density of stocking, although with considerable variation.

A negative relationship was also found between density of stocking and $\mathrm{SOC}$ in both soil horizons. The lowest SOC content in the surface mineral horizon was detected when density of stocking was 0.91.0 and stands were mostly in the $4^{\text {th }}$ and $5^{\text {th }}$ age class (Fig. 3 ). It is possible to conclude that the denser the forest is, the more stable the conditions are for decomposition and humification (Brady \& Weil 2002), which reduce SOC content in the soil. Conversely, stands with open canopy with lower values of density of stocking (e.g., 0.3, 0.4 and 0.7) are able to sequester more carbon into the soil, especially into the mineral horizon. Moreover, a significant decreasing trend of $\mathrm{SOC}$ with increasing AHYC (absolute height-yield class) was observed only in the organic horizon, suggesting a significant impact of climatope. Stands with higher yield class of trees, and thus with lower SOC content in soil, are located mainly in the $3^{\text {rd }}$ to $6^{\text {th }} \mathrm{FVZ}$, where the rate of decomposition and humification is faster, which is evident in the prevailing humus form moder. Stands with lower yield class and higher SOC content are located in the $7^{\text {th }}$ and $8^{\text {th }} \mathrm{FVZ}$ (i.e., at sites with a natural occurrence of stands dominated by Norway spruce), where the prevailing humus form is mor, the decomposition processes take place only marginally and the carbon is stored in the soil. As for the AHYC values 16,22 , and 32 , which do not conform with the general trend described above (Fig. 4), they include stands occurring on Haplic Podzol and Entic Podzol soil types. As mentioned above, this group of soils is distinguished by a distinctly higher SOC content in both horizons (Tab. 1, Fig. 6), probably due to the humus form present (Tab. 1).

Our results demonstrated a significant influence of altitude and soil group on SOC content in both soil horizons. In particular, the nature of soil (Podzol or non-Podzol) seems to be an important factor that could explain the significant differences in the SOC content observed in both soil horizons. However, stands of the Podzol soil group are located at the highest altitudes (mountain Podzol) in the study area, and are characterized by extreme values of SOC content, therefore outliers were not removed from the dataset. Nonetheless, the increasing trend of $\mathrm{SOC}$ content in both soil horizons along the altitudinal gradient (expressed in terms of FVZ - Fig. 5) is consistent with previous findings reported by Garten \& Hanson (2006) and Tashi et al. (2016). Moreover, the lowest SOC content in the surface mineral horizon was found for stands located in the $3^{\text {rd }}$ and $4^{\text {th }}$ FVZ (365-580 $\mathrm{m}$ a.s.l.), as well as in the $4^{\text {th }}$ and $6^{\text {th }}$ age classes with density of stocking around 0.9, with AHYC in the range of 18 to 28 , where the decomposition process is faster (Fig. 5). These positions are unnatural for Norway spruce in the study area. Based on our results, no significant carbon storage into the soil occurs at these elevations. Furthermore, in the context of regional scenarios of anticipated global climate change (Čermák et al. 2004) and related shift in FVZ, Norway spruce growing outside of its ecological and climatic optimum is expected to suffer of impaired health conditions, reduced growth and ultimately to high mortality (already evident at present). In this context, stands with dominant Norway spruce at the lowest elevation sites are unlikely to reach the $6^{\text {th }}$ age class (around 120 years), when, according to our findings, they begin to show the ability for carbon sequestration into the soil (Carey et al. 2001, Luyssaert et al. 2008).

A high and increasing SOC content in both soil horizons was found for stands located from $5^{\text {th }}$ to $8^{\text {th }} \mathrm{FVZ}(770-1225 \mathrm{~m}$ a.s.l.), with the highest SOC content in the $8^{\text {th }} \mathrm{FVZ}$ (Fig. 5). There is a slowing of the decomposition process and the accumulation of soil organic matter (Drewnik 2006) due to climatic conditions. It can be stated that in these positions, the most significant carbon sequestration into the soil occurs, especially into the mineral horizon.

Norway spruce forest stands reached the highest yield class in the current $4^{\text {th }}, 5^{\text {th }}$ and $6^{\text {th }} \mathrm{FVZ}$ in the study area. At higher altitudes AHYC declines, mainly due to the effects of climatope. With the expected climate change and the associated shift of FVZ, in terms of process of AHYC, the potential for carbon sequestration into the soil by Norway spruce forests will probably be higher at higher FVZ (i.e., elevation Fig. S4 in Supplementary material), where Norway spruce naturally occurs and at sites with prevailing Haplic Podzol and Entic Podzol soil types, which showed the highest stock of SOC.

Based on the obtained results, it is apparent that forest stands with a natural dominance of Norway spruce growing at higher altitudes (from $6^{\text {th }}$ to $8^{\text {th }} \mathrm{FVZ}$ ) in the $6^{\text {th }}$ to $8^{\text {th }}$ age class with lower density of stocking (sparse stands), have a significant ability to sequester carbon into the soil, especially in the surface mineral horizon. Conversely, production forest stands, predominantly in the $4^{\text {th }}$ to $5^{\text {th }}$ age class, at almost full density of stocking (from 0.9 to 1.0), and located at lower altitudes ( $3^{\text {rd }}$ and $4^{\text {th }} \mathrm{FVZ}$, marginally in the $5^{\text {th }} \mathrm{FVZ}$ ), showed a lower ability of carbon sequestration into the soil. According to many authors, Norway spruce stands of these age classes tend to demonstrate the ability to fix carbon in their biomass (Cienciala et al. 2006, Vilén et al. 2015, Parolari \& Porporato 2016).

Regional scenarios of expected climate change in the study area foresaw a shift of 1-2 forest vegetation zones (Čermák et al. 2004). This change will lead the optimum conditions for cultivation of Norway spruce to shift up to higher altitudes, i.e., towards the area of its natural distribution (Čermák \& Holuša 2010, Hlásny et al. 2011, Hanewinkel et al. 2013). Current Norway spruce stands at lower altitudes and on sites outside its natural habitat will be unsuitable for its further growth and survival (Čermák et al. 2004, Čermák \& Holuša 2010, Hlásny et al. 2011, Fitzgerald \& Lindner 2013, Hanewinkel et al. 2013). Several studies showed that forest stands with natural dominance of Norway spruce at higher altitudes (> $600 \mathrm{~m}$ a.s.l.) can be very important for carbon storage (Janssens et al. 2003, Vetter et al. 2005). Our results suggest that Norway spruce forest stands in their ecological optimum will be capable of long-term survival, sustainable growth and effective carbon sequestration.

\section{Conclusion}

Our results show that the studied stand characteristics (age, density of stocking and absolute height-yield class) and site conditions (soil type, humus form, elevation gradient) have an impact on the potential for carbon sequestration in the soil of forest stands dominated by Norway spruce in the eastern part of Czech Republic. A higher content of $\mathrm{SOC}$ was demonstrated in the surface mineral soil horizon compared to the organic horizon, which is desirable for the long-term stability of carbon sequestration in the soil.

According to our results, older stands (age: 101-190 years) with lower density of stocking (sparse stands), located in the elevation range $1010-1225 \mathrm{~m}$ a.s.l. $\left(6^{\text {th }}\right.$ to $8^{\text {th }}$ $F V Z$, i.e., the range of natural occurrence of the Norway spruce forest), have the highest potential for long-term stable carbon sequestration in the soil (especially in the mineral soil horizon), even in the context of expected climate change.

Priority adaptive measures should be considered to face the effects of anticipated climate change on carbon sequestration in the soil, including a change of forest management towards near-natural forms which respect the potential natural vegetation. Further research is needed to better assess the effectiveness of individual species (both individually and mixed) in preserving the "carbon service" outside locations and sites of natural representation of Norway spruce.

\section{Acknowledgements}

The authors would like to thank the Palacký University Grant Agency (project IGA 2015008) for supporting this work.

\section{References}

Andivia E, Rolo V, Jonard M, Formánek P, Ponette $Q$ (2016). Tree species identity mediates mechanisms of top soil carbon sequestration in a Norway spruce and European beech mixed forest. Annals of Forest Science 73 (22): 437447. - doi: 10.1007/s13595-015-0536-z

Berger T, Neubauer C, Glatzel G (2002). Factors 
controlling soil carbon and nitrogen stores in pure stands of Norway spruce (Picea abies) and mixed species stands in Austria. Forest Ecology and Management 159 (1-2): 3-14. - doi: 10.1016/ S0378-1127(01)00705-8

Birdsey RA, Platinga AJ, Heath LS (1993). Past and prospective carbon storage in United States forests. Forest Ecology and Management 58: 33-40. - doi: 10.1016/0378-1127(93)901 29-B

Brady NC, Weil RR (2002). The nature and properties of soils. Prentice Hall, New Jersey, USA, pp. 960.

Carey EV, Sala A, Keane R, Callaway RM (2001) Are old forests underestimated as global carbon sinks? Global Change Biolology 7 (4): 339344. - doi: 10.1046/j.1365-2486.2001.00418.x Ciais P, Schelhaas MJ, Zaehle S, Piao SL, Cescatti A, Liski J, Luyssaert S, Le-Maire G, Schulze ED, Bouriaud O, Freibauer A, Valentini R, Nabuurs GJ (2008). Carbon accumulation in European forests. Nature Geosciences 1: 425-429. - doi: 10.1038/ngeo233

Cienciala E, Henžlík V, Zatloukal V (2006). Assessment of carbon stock chase in forest - adopting IPCC LULUCF good practice guidance in the Czech Republic. Forestry Journal 52 (1-2): 17-28.

Čermák P, Jankovský L, Cudlín P (2004). Risk evaluation of the climatic change impact on secondary Norway spruce stands as exemplified by the Krtiny Training Forest Enterprise. Journal of Forest Science 50 (6): 256-262. - doi: 10.17221/4623-JFS

Čermák P, Holuša O (2010). Forestry adaptation measures at the decline of Norway spruce (Picea abies Karst.) stands as exemplified by the Silesian Beskids, CR. Acta Universitatis Agriculturae et Silviculturae Mendelianae Brunensis 59 (1): 293-302. - doi: 10.11118/actaun201159010293 Drewnik M (2006). The effect of environmental conditions on the decomposition rate of cellulose in mountain soils. Geoderma 132 (1-2): 116130. - doi: 10.1016/j.geoderma.2005.04.023

Fitzgerald J, Lindner M (2013). Adapting to climate change in European forests. Results of the MOTIVE Project. Pensoft Publishers, Sofia, Bulgaria, pp. 108. [online] URL: http://www. researchgate.net/publication/259821223

Frouz J, Pizl V, Cienciala E, Kalcik J (2009). Carbon storage in post-mining forest soil, the role of tree biomass and soil bioturbation. Biogeochemistry 94 (2): 111-121. - doi: 10.1007/s10533-00 9-9313-0

Garten CT, Hanson PJ (2006). Measured forest soil $C$ stocks and estimated turnover times along an elevation gradient. Geoderma 136 (12): 342-352. - doi: 10.1016/j.geoderma.2006.03.0 49

Grünwald T, Bernhofer C (2007). A decade of carbon, water and energy flux measurements of an old spruce forest at the Anchor Station Tharandt. Tellus series B Chemical and Physical Meteorology 59 (3): 387-396. - doi: 10.1111/j. 1600-0889.2007.00259.x

Gurmesa GA, Schmidt IK, Gundersen P, Vesterdal $L$ (2013). Soil carbon accumulation and nitrogen retention traits of four tree species grown in common gardens. Forest Ecology and Management 309: 47-57. - doi: 10.1016/j.foreco.2013.02. 015

Harper RJ, Tibbett M (2013). The hidden organic carbon in deep mineral soils. Plant and Soil 368 (1-2): 641-648. - doi: 10.1007/s11104-013-1600-9 Hanewinkel M, Cullmann DA, Schelhaas MJ, Nabuurs GJ, Zimmermann NE (2013). Climate change may cause severe loss in the economic value of European forest land. Nature Climate Change 3: 203-207. - doi: 10.1038/nclimate1687 Hiltbrunner D, Zimmermann S, Hagedorn F (2013). Afforestation with Norway spruce on a subalpine pasture alters carbon dynamics but only moderately affects soil carbon storage. Biochemistry 115 (1): 251-266. - doi: 10.1007/s10 533-013-9832-6

Hlásny T, Pajtík J, Balázs B, Barcza Z, Turčáni M, Fabrika M, Sedmák R, Churkina G (2011). Climate change impacts on growth and carbon balance of forests in Central Europe. Climate Research 47: 219-236. - doi: 10.3354/cro1024 IPCC (2000). IPCC special report: land use, landuse change and forestry. Summary for Policymakers. Intergovermentnal Panel on Climate Change, WMO, UNEP, pp. 30. [online] URL: http://www.ipcc.ch/pdf/special-reports/spm/srl -en.pdf

James J, Devine W, Harrison R, Terry T (2014). Deep soil carbon: quantification and modeling in subsurface layers. Soil Science Society of America Journal 78: 1-10. - doi: 10.2136/sssaj20 13.06.0245nafsc

Jandl $R$, Lindner $M$, Vesterdal L, Bauwens $B$, Baritz R, Hagedorn F, Johnson DW, Minkkinen K, Byrne KA (2007). How strongly can forest management influence soil carbon sequestration? Geoderma 137 (3-4): 253-268. - doi: 10.101 6/j.geoderma.2006.09.003

Janssens IA, Freibauer A, Ciais P, Smith P, Nabuurs GJ, Folberth $G$, Schlamadinger $B$, Hutjes RWA, Ceulemans R, Schulze ED, Valentini R, Dolman AJ (2003). Europe's terrestrial biosphere absorbs 7 to $12 \%$ of European anthropogenic $\mathrm{CO}_{2}$ emissions. Science 300 (5625): 1538-1542. - doi: 10.1126/science.1083592

Kern VN, Cremer M, Prietzel J (2016). Soil organic carbon and nitrogen stocks under pure and mixed stands of European beech, Douglas fir and Norway spruce. Forest Ecology and Management 367: 30-40. - doi: 10.1016/j.foreco. 2016.02.020

Körner C (2006). Plant $\mathrm{CO}_{2}$ responses: an issue of definition, time and resource supply. New Phytologist 172 (3): 393-411. - doi: 10.1111/j.1469-8137. 2006.01886.x

Laganière J, Paré D, Bergeron $\mathrm{Y}$, Chen $\mathrm{HYH}$ (2012). The effect of boreal forest composition on soil respiration is mediated through variations in soil temperature and $\mathrm{C}$ quality. Soil Biology and Biochemistry 53: 18-27. - doi: 10.1016/j. soilbio.2012.04.024

Lorenz K, Lal R (2010). Carbon sequestration in forest ecosystems. Springer Netherlands, New York, USA, pp. 279.

Lundmark T, Bergh J, Nordin A, Fahlvik N, Poudel Ch B (2016). Comparison of carbon balances between continuous-cover and clear-cut forestry in Sweden. Ambio 45 (2): 203-213. - doi: 10.1007/ s13280-015-0756-3

Luyssaert S, Schulze ED, Börner A, Knohl A, Hessenmöller D, Law BE, Ciais P, Grace J (2008). Old-growth forests as global carbon sinks. Nature 455: 213-215. - doi: 10.1038/nature07276

Marek MV, Ač A, Apltauer J, Bodlák L, Burešová
R, Cienciala E, Cudlín P, Cudlínová E, Czerny R, Čížková H, Dubrovský M, Dušek J, Exnerová Z, Havránková K, Henžlík V, Janderková J, Janouš D, Lapka M, Macků J, Matějka K, Pavelka M, Pechal L, Pokorný J, Pokorný R, Schneider J, Stará L, Středa T, Šerna L, Taufarová K, Tomášková I, Urban O, Vyskot I, Zatloukal V, Zemek F, Zitová M (2011). Uhlík v ekosystémech České republiky v měnícím se klimatu [Carbon in ecosystems of Czech Republic in changing climate] ( $1^{\text {st }}$ edn). Academia, Prague, Czech Republic, pp. 255. [in Czech]

Nelson DW, Sommers LE (1982). Total carbon, organic carbon, and organic matter. In: "Methods of soil analysis: Part 2 Chemical and microbiological properties" (Page AL, Miller RH, Keeney DR, eds). American Society of Agronomy, Soil Science Society of America, Academic Press, Madison, WI, USA, pp. 539-580.

Oostra S, Majdi H, Olsson M (2006). Impact of tree species on soil carbon stocks and soil acidity in southern Sweden. Scandinavian Journal of Forest Research 21 (5): 364-371. - doi: 10.108 o/02827580600950172

Parolari AJ, Porporato A (2016). Forest soil carbon and nitrogen cycles under biomass harvest: stability, transient response, and feedback. Ecological Modelling 329: 64-76. - doi: 10.1016/j.ecolmodel.2016.03.003

Post WM, Peng TH, Emanuel W, King AW, Dale $\mathrm{VH}$, De Angelis DL (1990). The global carbon cycle. American Scientist 78 (4): 310-326. [online] URL: http://www.as.wvu.edu/biology/bio463/gl obalcarbon.pdf

Pretzsch H, Biber P, Schütze G, Uhl E, Rötzer T (2014). Forest stand growth dynamics in Central Europe have accelerated since 1870 . Nature Communications 5 (1): 349. - doi: $10.1038 /$ ncom ms5967

Rumpel C, Kögel-Knabner I (2011). Deep soil organic matter - a key but poorly underwood component of terrestrial $C$ cycle. Plant and Soil 338 (1): 143-158. - doi: 10.1007/s11104-010-0391-5 Světlík J, Krejza J, Pokorný L, Menšík L, Kulhavý J, Mazal P (2016). Sekvestrace uhlíku smrkovým porostem (Picea abies (L.) Karst.) v oblasti Drahanské vrchoviny [Carbon sequestration into a spruce stand (Picea abies (L.) Karst.) in the Drahanská vrchovina upland]. Zprávy lesnického výzkumu [Messages from Forestry Research] 61: 42-53. [in Czech]

Tashi S, Singh B, Keitel C, Adams M (2016). Soil carbon and nitrogen stocks in forests along an altitudinal gradient in the eastern Himalayas and a meta-analysis of global data. Global Change Biology 22 (6): 2255-2268. - doi: 10.1111/ gcb.13234

Vesterdal L, Schmidt IK, Callesen I, Nilsson LO, Gundersen P (2008). Carbon and nitrogen in forest floor and mineral soil under six common European tree species. Forest Ecology and Management 255 (1): 35-48. - doi: 10.1016/j.for eco.2007.08.015

Vesterdal L, Clarke N, Sigurdsson BD, Gundersen $P$ (2013). Do tree species influence soil carbon stocks in temperate and boreal forests? Forest Ecology and Management 309: 4-18. - doi: 10.1016/j.foreco.2013.01.017

Vetter $M$, Wirth $C$, Böttcher $H$, Churkina $G$, Schulze ED, Wutzler T, Weber G (2005). Partitioning direct and indirect human-induced ef- 
fects on carbon sequestration of managed coniferous forests using model simulations and forest inventories. Global Change Biology 11 (5): 810-827. - doi: 10.1111/j.1365-2486.2005.00932.x Viewegh J, Kusbach A, Mikeska M (2003). Czech forest ecosystem classification. Journal of Forest Research 49 (2): 85-93.

Vilén T, Cienciala $E$, Schelhaas $M J$, Verkerk PJ, Lindner M, Peltola H (2015). Increasing carbon sinks in European forests: effects of afforestation and changes in mean growing stock volume. Forestry 89 (1): 82-90. - doi: 10.1093/for estry/cpv034

Wiesmeier M, Prietzel J, Barthold F, Spörlein P, Geuss U, Hangen E, Reischl A, Schilling B, Von Lützow M, Kögel-Knabner I (2013). Storage and drivers of organic carbon in forest soils of southeast Germany (Bavaria) - implications for carbon sequestration. Forest Ecology and Management 295: 162-172. - doi: 10.1016/j.foreco.20 13.01.025

WRB (2014). World reference base for soil re- sources 2014 (update 2015). International soil classification system for naming soils and creating legends for soil maps. World Soil Resources Reports no. 106, Food and Agriculture Organization, Rome, Italy, pp. 203. [online] URL: http://www.fao.org/3/i3794en//3794en.pdf

\section{Supplementary Material}

Tab. S1 - Frequency of the studied plots according to ecological series and edaphic categories.

Tab. S2 - Frequency of the analysed samples from the monitoring plots, according to density of stocking and stand age class.

Tab. S3 - SOC content (t ha $\left.{ }^{-1}\right)$ in the organic $(O)$ and surface mineral (A) soil horizon, according to stand age class.

Tab. S4 - SOC content (t ha ${ }^{-1}$ ) in the organic
(O) and surface mineral (A) soil horizon, according to density of stocking of forest stands.

Fig. S1 - Location of the study area and monitoring plots. (1): Drahanská vrchovina Upland; (2): Jeseníky Mountains.

Fig. S2 - Variation of SOC content ( $\left.\mathrm{t} \mathrm{ha} \mathrm{a}^{-1}\right)$ in the surface mineral soil horizon in relation to the absolute height-yield class (AHYC).

Fig. S3 - Comparison of SOC content (t ha $\left.{ }^{-1}\right)$ in the organic $(O)$ and surface mineral $(A)$ soil horizon according to the humus forms present in the analysed dataset.

Fig. S4 - Variation of median values of absolute height-yield class (AHYC) in each represented forest vegetation zones (FVZ).

Link: Becvarova_2521@supploo1.pdf 